\title{
Either / Or-why ideas, science, imperialism, and institutions all matter in the "rise of the west"
}

\author{
JACK A. GOLDSTONE
}

Hong Kong University of Science and Technology George Mason University

Deirdre McCloskey has now completed the third (and final?) volume of her trilogy on how the West (from 1800 to 1950) and most of the rest of the world (from 1900 to 2015) grew rich. The message of all three volumes is spelled out in the subtitle: "How ideas, not capital or institutions, enriched the world".

The latest volume has much that is right, and a few things that are wrong; all are important. The book is also a tribute to the view that history's finest accomplishments are made late in careers, when one has not only absorbed but mastered a wide variety of materials. In this volume we are treated to McCloskey's finest displays of erudition to date. Her arguments range from in-depth analysis of English literature (notably tracing the marked differences in attitudes toward the bourgeoisie from Shakespeare to Jane Austen but also including Swift, Addison, Steele, Defoe, Fielding, Trollope, Pepys, Johnson) to philosophy (Adam Smith, David Hume, J.L. Austin, Wittgenstein) to hundreds of modern historians, economists, sociologists, and political scientists. We learn details ranging from the frequency of rape in Papua New Guinea to the controversy over temple distribution as the economic basis of Mesopotamian civilization. It is fascinating, eloquent, and richly entertaining.

Throughout, a simple argument is honed. We are rich, rich, rich, beyond the imaginings of any utopian or scholar, banker or king who lived before 1700. If every peasant in England enjoyed the comforts of a castle comparable to that of Henry VIII, they still would not have had the comfort and light that well-insulated homes with central heat and electric light provide to the modern average North American or 
European; they would not have had the variety of food and clothing available to twenty-first century urban Chinese and Indians; they would not have enjoyed the average life-span of today's Nigerians or Ethiopians.

In the last two-hundred years we have created a world in which peasants can use smartphones to learn the market prices and weather affecting their crops, in which craftsmen and shop-owners can fly to tropical vacations on other continents, and in which almost any urbanite in India or China as well as the West can watch television and communicate with friends thousands of miles away. This seems so familiar now that it is easy to imagine this progress as ordinary, slow but steady, and almost inevitable.

Yet McCloskey insists that we recognize how amazing, fabulous, and contrary to all odds this was. It was certainly not inevitable, or a matter of the slow and steady growth of commerce and invention. If it was, those highly commercial Mesopotamians, Romans, and Venetians and highly inventive Chinese and Muslims would have gotten rich hundreds or thousands of years earlier. They did not; so why, in the historical blink of an eye, did the West?

Here McCloskey continues her argument that ideas-or to be more precise, the spread of a specific highly radical set of ideas-was the cause. Not that other factors were not necessary. Private property, limits on the ability of guilds and states to throttle change, reformation in religion, printing, literacy, and even the occasional political revolution all played a role. But none of these were sufficient conditions to create the "Great Enrichment" of the last two hundred years. McCloskey compares all of these conditions, which can be found in many civilizations across history, to the accumulation of dry wood and brush in a forest. To set them alight, not only an initial spark is needed. It is also the case that elites must be unable to keep dousing the fires. What can prevent the elite from preventing change, when the status quo so strongly favors their interests? An insistence that ordinary people should be encouraged to act independently, be respected for originality and innovation, and be allowed to retain (most of) the profits of any activities they offer in free and fair markets.

These conditions too, nowadays seem so pedestrian that we might treat them as commonplace, and look elsewhere for a more dramatic cause for the sudden acceleration of wealth production after 1800 . Economists and political scientists look to institutions, claiming they 
were radically changed after 1689 in Britain; historians sometimes look to modern science as it emerged after 1500 in Europe; sociologists from Marx and Weber to Wallerstein point to a shift in "capitalist relations" starting around the same date.

McCloskey repeats her criticisms of these approaches from earlier volumes. No, institutions did not change radically after 1689: Kings, lords, and gentlemen still ruled Britain and its shires up through 1832. Modern science had no direct impact on the hundreds of practical inventions that arose in Britain from the spinning jenny, water frame and mule to the steam engine, railroad, rotary saw, cutting lathe, cokefired steel furnace, macadamized roads, and so forth. As for capitalism, neither the class relations, nor the psychology, nor the gains from longdistance trade changed in a measurable degree before 1800. Since Mesopotamia and Egypt four and five millennia ago, merchants bought raw materials or manufactured goods, employed workers, and sold to consumers, seeking to earn profits on the difference between the final sale and earlier purchases. Whether working in long distance trade (whether taking Chinese manufactures along the silk road, or gold across the Sahara, or horses from central Asia, or European woolens and tapestries to Byzantium and Turkey) or in more local exchanges, the principles were the same and in general, the higher the risks the higher the rewards.

What triggered the change, according to McCloskey, was a revaluation of that humble merchant activity. Throughout most of history and all civilizations, a basic knowledge of economics was sorely lacking. Not understanding how markets in equilibria maximize efficiency among varied producers and consumers, the ability of merchants to grow rich without actually growing or making anything seemed to be some kind of thinly-veiled theft. Farmers could grow food and commercial crops; craftsmen could create clothing, furniture, build churches and gardens, and of course lords could shed blood to win property and loot. But how does trading one thing for another create fortunes? Either the things traded were of equal value, in which case the trade was fair but yields no profit; or the merchant is trading something of lower value for something of greater value, which requires lying or cheating. Hence the typical depiction of merchants in literature as lying, cheating money-grubbers, who only make a profit by being more attentive to and manipulative about values and exchange than befits any honorable man. 
With merchant activity so scorned, it was natural for it to be highly regulated and taxed (toll roads and gates proliferated). To be respected, mercantile fortunes had to be traded for respectable offices or military ranks, and children sent to the right schools to "wash off" the stain of merchant origins.

As to the profits from innovation in products or processes, those were doubly damned-first as profits originating in trade, second from innovations that threatened the vested interests of other producers and merchants. Guild restrictions thus specified output and quality and throttled change; innovation and novelty were cursed as undermining the "natural order" (much like genetically-modified crops even today).

Yet somehow-and McCloskey has the courage to say "the causes were local, temporary, and unpredictable" (p. 359)-this changed in Western Europe. First in Venice, then Florence, then Holland, and then Britain, wealth gained by commerce acquired a sheen of respectability and even virtue. New enterprises spurred by invention-Venetian glassworks and paper; Florentine banking and luxury silk and leather goods; Dutch fishing, windmills, textiles, and commercial farming; and British cotton, steel, and steam-power-became routes to wealth and respectability. To be sure, in Venice, Florence, and Holland the sparks died out or sputtered to a slow and steady glow: the most successful merchants became regents and increasingly lived as rentiers off their accumulated capital, forsaking innovation and leaving the expanding of markets to others. But in Britain the encouragement of ordinary people to innovate and build and trade and profit continued, producing generation after generation of greater innovations. Instead of retrenching, the hierarchy of rank was weakened and eventually broken, at least in economics (although oddly Britain retains a House of Lords to this day, which was hereditary until very recently). Over the course of six or seven generations, each one doubling the wealth of its predecessor, the riches of the modern world emerged.

In McCloskey's view, this revaluing of the contributions of ordinary people unleashed such a torrent of innovations and "betterment" that we have all gained a hundred-fold from it. It is a very convincing story, as McCloskey's hundreds of examples from literature and history make it quite clear that in Shakespeare's day (and in Imperial China and Shogunal Japan and Mughal India) merchant activity was shameful and scorned, but by the 19th century the same activity was regarded as the 
source of national wealth, and something to be honored and deserving of reward. Ideas changed, and the world was transformed.

Yet for all its convincing detail, two questions still nag as one reads this story. First, why did this change in ideas occur? McCloskey cannot say. It seems to have begun many times in history. From Carthage to Tyre, the Phoenicians built an empire on trade and according to the Bible "her traders [were] the most honored men on earth" (Isaiah 23:8, quoted by McCloskey, p. 640). In the 9th-11th centuries, the Persians and Arabs built empires on trade, following a Prophet who was himself a merchant, and pioneered navigational aids and sea routes that linked the Mediterranean and Indian Oceans. Venice, Genoa, Portugal, and Holland all built empires on trade and created "merchant-princes." The merchants of Osaka ran their own society and at times lorded it over the Shogun of Edo. So why did these examples fade while the shift in ideas in England did not? Why did the shift in rhetoric to value the bourgeoisie in England not simply evolve as it did in all other cases, namely to create an oligarchy of privileged merchants who still derided ordinary citizens? Why in England did the shift continue and go further-as prefigured as early as the 1640 s by the Levellers-to fullblown legal equality, religious tolerance, and domination of the House of Lords by the House of Commons, an inversion of the "Great Chain of Being" as it had existed for a millennium? McCloskey, to her credit, does not claim she can give a necessary and sufficient answer. It is enough to clearly demonstrate that this revaluation occurred, that it was sustained only in Britain after 1700, and that this change was the only change sufficiently rapid and radical to account for the sudden onset of exponential economic growth.

Second, one also has to ask, why did the revaluing of mercantile activity and the worth of common individuals suffice to ignite not merely great efforts to create wealth, but an amazing torrent of truly innovative changes in basic products and processes? To say that Thomas Newcomen, inventor of the steam engine (and still derided today by many, including McCloskey, as a merely skilled artisan or tinkerer), or John Smeaton, the first modern civil engineer, or the Reverend Edmund Cartwright, inventor of the power loom (whose mill was repossessed and an early factory using his mills burned down) were more rewarded and respected than the Persian merchants or even Venetian and Dutch manufacturers of old seems just wrong. These men and thousands like them seem to have had a passion for invention, plus 
access to mechanical skills and calculations and equipment, that were simply missing in earlier merchant empires. So it could not just have been respect that produced their extraordinarily productive innovations. Something else must have happened as well.

McCloskey seems to believe that if ordinary people are just given the opportunity and encouragement to get rich-let the lords and states and guilds and others who try to fix markets and exclude entry just get out of the way-then productive innovations will flourish. Smithian growth will flow into Schumpeterian growth automatically, and the steam engine and cars and airplanes will be just a few generations away.

Yet can it truly be that simple? One may want to innovate to enrich oneself. But if you believe the only way to innovate is to create new styles or colors, or seek out new sources for products, or create a new product or process and then monopolize it, you can still be a fantastically successful merchant (which is what Phoenician, Persian, Venetian, and Dutch merchants did), but you will not set out on paths to the "Great Enrichment". How does anyone acquire the belief-based on no prior successful examples in history-that the best way to innovate is to perform thousands of experiments to create new products or processes as Wedgewood did to create Jasper blue (as McCloskey points out on p. 522), or Darby did to develop coke-fueled making and casting of iron, or to track the work of scientists in the Royal Society or Lunar Society or other forums of scholars for ideas (as Newcomen did through family and neighborhood connections to the Careys and the Hartlib circle [Greener 2016])? McCloskey cites Macaulay in 1830 prophesying that "in the year 1930 a population of fifty million, better fed, clad and lodged than the English of our time, will cover these islands [and] that machines constructed on principles yet undiscovered will be in every house" (p. 64). This radical technical utopianism seems to be something quite separate and distinct from the mere granting of respect to merchants and innovative artisans.

Indeed, by the end of the book, one may well end up asking-why does it have to be ideas OR institutions and capital? Why not all three plus more besides? After all, if the "Great Enrichment" is so remarkable, amazing, and new, unlike anything begun or produced in any time or place in history, why should it have been produced mainly by change in just one dimension of social life? Why not a host of linked changes, to ideas, institutions, and capital that created a virtuous circle of crossfertilization without a single primary cause? 
McCloskey here seems caught up in the mirror-problem affecting many scholars. If Acemoglu and Robinson, or North, Wallis and Weingast, focus on institutions and deny the role of ideas, then we will deny the role of institutions to show them that ideas really are what matters. McCloskey's claim that institutions did not change, or did not change fast enough or far enough to ignite the "Great Enrichment" rings hollow. If institutions did not change, then how could a change in rhetoric and ideas have had any impact in the real world? McCloskey tells us that innovation was constantly throttled by state interference, guilds, legal and religious hierarchy, and the absence of rights for ordinary individuals. A shift in ideas would not change any of these things unless institutions changed as well.

For what are institutions? They are not natural resources or geography or other objective entities unchained to thought (although even what counts as a natural resource or as geographic facts are also shaped by ideas). Institutions are simply ideas of proper behavior that have been codified by law or custom to become normative behavior. If ideas for what is proper normative behavior undergo a major alteration, then institutions should change as well.

Between 1620 and 1720, England experienced two revolutions, major changes in the rights and role of Parliament and the toleration of religious sects (codified in the Acts of 1688-89), the development of Whig and Tory parties, two changes in ruling dynasty, one a Dutch ruler who imported many Dutch practices and the other a German, nonEnglish speaking king who increasingly relied on ministers and Parliaments to manage state affairs. Not incidentally, the period also saw the rise of the Royal Society and Gresham College, numerous provincial scientific societies, the Union of England and Scotland, the founding of the American colonies, and major victories over Spain and France that shifted the balance of power in Europe and established Britain as a major power. It is hard to argue that Britain thus had no significant or rapid institutional changes prior to the "Great Enrichment", or that none of these institutional changes mattered for the history of ideas in Britain, or mattered for subsequent economic growth. McCloskey's bourgeois revaluation may have been necessary, even vital, to unleashing the creative powers of the many; but the history is just too complex to say that institutions mattered not at all.

Similarly, the claim that capital was irrelevant because capitalism had always been present (contra-Polanyi) does not do the job of 
excluding capital from any role. It depends on what is meant by 'capital'. Accumulation by market means is as old as civilization, as McCloskey rightly insists. But the specific instruments of capital have changed. The progression from stone axes to forged steel swords, from horse-drawn pumps to windmills and steam engines, and from building in wood and stone to brick and iron are all fundamental changes in the composition of capital that are not captured simply in terms of "capital accumulation". The same is true for human capital. Literacy may not have been greater in 17th century Britain than in contemporary China. But unlike in China, thinkers and craftsmen in Britain had new tools to work with, including skills in experimental apparatus and observing instruments; new calculating tools such as logarithms and mastery of Arabic numerals; and a novel blending of geometry and algebra in Cartesian coordinates.

One could also turn McCloskey's bourgeois revaluation on its headinstead of asking why it was that ordinary merchants and tradesmen were granted more respect, one could ask why Kings and nobles were granted less. What undermined the authority of the great hierarchies that had dominated religious and political power for a thousand years in Europe? Why did popes and bishops and kings cease to be able to shape thought and command obedience such that between 1640 and 1848 waves of anti-monarchical and anti-clerical revolutions spread across the continent?

One part of the answer of course lies with the Reformation. That shift in ideas, impelled by Martin Luther's revulsion at the corruption and hypocrisy of the Catholic hierarchy, undermined numerous prelates and monarchs and unleashed new egalitarian politics from Scotland to Geneva. Yet the egalitarian force of the Reformation was largely blunted by 1700 . The restoration of Anglican monarchy in Britain, and the rise of strong monarchies in Lutheran Sweden and Prussia, restored much of the old order under a new state Church. Even in the Netherlands, by the early 18th century the dominance of the increasingly exclusivist Dutch Reformed Church diminished tolerance of religious sects and minorities.

Perhaps equally important was the loss of confidence in the classical edifice of knowledge inherited from the High Middle Ages. The medieval scholastics labored long and hard over a difficult problem-how to reconcile the revelations of the Bible with the newly retrieved works of classical authors flooding into Europe from Spain and Byzantium? In the crowning work of St. Thomas Aquinas, Plato was subordinated to 
Aristotle, and Aristotle's works were reconciled and integrated with the Bible and Church Fathers. Ptolemy, Galen, and other ancient masters were also absorbed and reconciled with divine text. The Renaissance didn't challenge this process, but rather amplified it. The increasing familiarity with and admiration for ancient authors and their accomplishments in art, architecture, philosophy, politics, mathematics, astronomy and geography cemented the union of the two strongest foundations for authority-divinity and tradition. By the fifteenth century, European universities had a rigorous curriculum based on theology and classical philosophy, joined with mathematical and empirical classical learning.

Yet in the sixteenth and seventeenth centuries, this edifice was shattered in a way unlike that in any other civilization. The discovery of the New World may not have done much to directly enrich Europe, as the new calculus of imperialism discussed by McCloskey has shown. But by exposing Ptolemy's geography as radically incomplete, it raised the possibility that ancient learning was flawed. Further scientific discoveries-Vesalius's anatomy, Harvey's demonstration of the circulation of the blood, Brahe's and Kepler's accounts of supernovae and comet's orbits, Galileo's analysis of projectile motion-all demonstrated that Aristotle's view of nature was as false and incomplete as Ptolemy's geography. Copernicus's solar-centered model of the planetary orbits, strengthened by Kepler's observations and then elegantly explained by Newton, wholly undermined both the Biblical and Aristotelian/Ptolemian cosmography. The amazing success of Newton's gravitational model in explaining everything from the motion of projectiles and centripetal forces to the shape of the spinning Earth and the tides, and its applications to fluid mechanics by French and Swiss mathematicians, gave $17^{\text {th }}$ and 18 th century natural philosophers confidence that modern thinkers could and had surpassed the ancients.

This too was a great inversion; most societies had looked at their past as a golden age, making the idea of 'progress' to a better-than-ever future not only laughable but heretical. But by the time of Francis Bacon, it was possible to conceive of a future in which mankind had amassed more and more valuable and powerful information than ever before. More importantly, along with this conceit came a technique for its realization-the testing of ideas by experiments with apparatus, shared and confirmed by an audience of fellow inquirers. Eighteenth century England was not only more open to individual efforts acquiring rewards; 
as Margaret Jacob (2014) has shown, it had dispersed knowledge of mechanics and of experimental methods and possession of scientific instruments to a far wider body of literate men and women than had ever been the case. Enterprising manufacturers and tradesmen like Newcomen and Calley, Darby and Wedgewood and Cort, as well as Arkwright and Crompton and Watt and Boulton, could draw on more precise measurement and experiments, new measuring tools and skills, and shared ideas and criticism, to advance their projects.

England after 1700 thus had a unique confidence and passion for invention, and unique tools and methods to advance invention, creating a situation where for the first time in history invention itself was widely and routinely sought and accessible. And as science advanced, it reinforced and multiplied these trends. The Industrial Revolution, from Newcomen's invention of the atmospheric steam engine in 1712 to the Crystal Palace Exhibition of 1851, was just the warm-up for the "Great Enrichment". In this period, the gains in science had the impact of inspiring a desire for innovation and providing methods for its realization, but not yet of offering discoveries that would transform economies. That changed after 1850, with advances in chemistry, electricity, thermodynamics, hydraulics, and scientific engineering leading to new dyes, artificial fertilizers, lighting and heating, hydroelectric power and eventually flight, radar, radio, telegraphy, and more.

At the same time, the undermining of the authority of Aristotelian and biblical accounts of nature led to a wider skepticism about the faultless authority of popes and the divine rights of kings. The new methods of scientific thought could lead to conflicting views in politics, from Hobbes's deduction that only an absolute sovereign could impose needed order on society to Locke's arguments that sovereignty was only valid if accepted by citizens. But faith in reason to triumph over the old authority of revelation and tradition was now empowered; and from the arguments of the Levellers to those of Jefferson and Paine and Hamilton to the "Rights of Man", indeed the entire Enlightenment project, we see the impact of the discovery of the New World and supernovae and laws of motion on the trajectory of European thought.

Did ideas change the world? Of course they did! But not only ideas of bourgeois revaluation. Also ideas of the power of reason vs. revelation and tradition; ideas of the power of citizens over popes and monarchs and of constitutions and laws and assemblies; and ideas of 
how experiment and measurement and invention could create material progress. And not only ideas-voyages of discovery, observations of the heavens, changes in dynasties, victories and defeats in wars, religious wars and reformations and sects, the discovery of atmospheric pressure and the properties of vacuums, the growth of cities, advances in agriculture-all played a role.

The "Great Enrichment" was such a radical rupture with all that had come before, something so improbable and exceptional, that it hardly makes sense to try to explain it in terms of this or that, a "grand cause" producing a grand effect. It was rather the result of a large number of changes that had accumulated over the previous centuries, changes that undermined traditional authorities, kindled a thirst and confidence for innovation, provided new tools for analysis and measurement and new understandings of society and nature.

McCloskey has written a beautiful and engaging book, and done a great service by demonstrating, contra mainstream economists and political scientists, the vast power of ideas to reshape society. Yet we should not err by following her too far. Much yet remains to be done to understand and integrate all the changes that had to arise for the "Great Enrichment" to occur. These involved ideas, politics, science, war, religion, exploration, and more. It is not either/or, but how it all came together, that we must explain.

\section{REFERENCES}

Greener, James. 2016. The design of accidents: Thomas Newcomen as empiricist. Unpublished manuscript.

Jacob, Margaret S. 2014. The first knowledge economy: human capital and the European economy, 1750-1850. Cambridge: Cambridge University Press.

Jack A. Goldstone is Elman Family professor of public policy at the Hong Kong University of Science and Technology and Hazel professor of public policy at George Mason University. His research examines longterm economic growth, democratization, the impact of demographic change on security and prosperity, and the causes and outcomes of revolutions in world history. Recent publications include Political demography: how population changes are reshaping international security and national politics (with Eric Kauffman and Monica Duffy Toft, Oxford University Press, 2012), Revolutions: a very short introduction (Oxford University Press, 2014), and The concise encyclopedia of comparative sociology (with Masamichi Sasaki, Ekkart Zimmerman, and Stephen K. Sanderson, Brill, 2014).

Contact e-mail: <jgoldsto@gmu.edu> 